\title{
PENGETAHUAN GURU MENGENAI SISTEM PEMBELAJARAN ALAMIAH OTAK DI TK MUJAHIDIN 1 PONTIANAK
}

\author{
Desni Yuniarni \\ Dosen Prodi PG PAUD FKIP Untan, Pontianak \\ Email: yuniarnidesni@yahoo.com
}

\begin{abstract}
Abstrak: Anak akan optimal dalam belajar apabila pembelajaran yang diberikan oleh guru sesuai dengan karakteristik perkembangannya. Proses pembelajaran itu sendiri terdiri dari komponen yang berbeda-beda, yang saling terkait satu sama lain. Komponen yang dijadikan fokus dalam penelitian ini adalah proses pembelajaran, yaitu bagaimana proses penyampaian materi pembelajaran dilakukan oleh guru di PAUD. Barbara K. Given dalam bukunya Brain Based Teaching (2007) mengatakan bahwa pendidikan lebih dari sekedar meraih standar pembelajaran tertentu, pendidikan identik dengan mengembangkan keinginan untuk belajar, memahami cara belajar dan menerapkan praktek pengajaran berdasarkan bagaimana sesungguhnya otak berfungsi. Mengacu pada pendapat Barbara diatas, proses penyampaian materi pembelajaran yang diberikan oleh guru kepada anak didiknya di TK hendaknya disesuaikan dengan bagaimana cara kerja otak anak dalam belajar. Pendidikan memiliki tujuan mengoptimalkan penggunaan otak. Tidak saja untuk aspek rasional-kognitif, tetapi juga emosi, fisik dan spiritual. Otak yang optimal adalah otak yang semua potensinya teroptimalkan dengan baik. Untuk dapat mengoptimalkan kerja otak dengan cara yang natural, Barbara menyebutnya sistem pembelajaran alamiah otak, yaitu sistem pembelajaran emosional, sosial, kognitif, fisik dan reflektif. Kelima sistem pembelajaran alamiah otak tersebut merupakan satu kesatuan yang harus ada dalam sistem pembelajaran yang disampaikan oleh guru kepada anak didiknya. Penelitian yang berkaitan dengan bagaimana kinerja otak anak usia dini dalam proses pembelajaran penting dilakukan untuk mengoptimalkan hasil pembelajaran pada anak usia ini, oleh karena itu peneliti tertarik untuk mengetahui sejauhmana pengetahuan yang dimiliki oleh para guru TK dengan metode deskriptif dan menggunakan angket dan lembar wawancara sebagai alat pengumpul datanya. Metode analisis yang yang digunakan adalah analisis deskriptif persentase. Hasil dari penelitian ini menunjukkan para guru di TK Mujahidin Pontianak memiliki pengetahuan yang sangat baik terhadap metode pembelajaran berbasis kinerja otak.
\end{abstract}

Kata Kunci : Anak Usia Dini, Pembelajaran Berbasis Kinerja Otak

\section{PENDAHULUAN}

Pendidikan

merupakan upaya

anak usia dini untuk menstimulasi, membimbing, mengasuh dan memberikan pembelajaran yang mampu menghasilkan kemampuan dan keterampilan anak. Pendidikan yang diberikan kepada anak pada usia dini, berlandaskan pada kebutuhan anak, yang disesuaikan dengan nilai-nilai yang dianut di lingkungan di sekitarnya, sesuai

dengan tahap perkembangan fisik dan psikologis anak, dilaksanakan dalam suasana bermain yang menyenangkan serta pembelajaran yang diberikan dirancang untuk mengoptimalkan seluruh potensi anak.

Anak akan optimal dalam belajar apabila pembelajaran yang diberikan oleh guru sesuai dengan karakteristik perkembangannya. Proses pembelajaran itu sendiri terdiri dari komponen yang berbeda-beda. Menurut Adi W. Gunawan (2003), dalam setiap proses pembelajaran, selalu akan ada tiga komponen penting yang saling terkait satu sama lain. Tiga komponen penting itu adalah kurikulum, yaitu materi yang akan diajarkan, proses yaitu bagaimana materi diajarkan dan produk yaitu hasil dari proses pembelajaran. Ketiga aspek ini sama pentingnya karena merupakan 
satu kesatuan yang membentuk lingkungan pembelajaran. Dalam hal ini penulis memfokuskan pada proses pembelajaran, yaitu bagaimana proses penyampaian materi pembelajaran dilakukan oleh guru di PAUD.

Barbara K. Given dalam bukunya

Brain Based Teaching (2007) mengatakan bahwa pendidikan lebih dari sekedar meraih standar pembelajaran tertentu, pendidikan identik dengan mengembangkan keinginan untuk belajar, memahami cara belajar dan menerapkan praktek pengajaran berdasarkan bagaimana sesungguhnya otak berfungsi. Mengacu pada pendapat Barbara diatas, proses penyampaian materi pembelajaran yang diberikan oleh guru kepada anak didiknya di PAUD hendaknya disesuaikan dengan bagaimana cara kerja otak anak dalam belajar.

Penggunaan riset-riset otak dalam dunia pendidikan wajib dilakukan. Bukan saja karena pendidikan mensyaratkan adanya otak (betapa sulitnya mendidik orang yang tak berotak atau otak nirnormal), tetapi juga karena pendidikan memiliki tujuan mengoptimalkan penggunaan otak. Tidak saja untuk aspek rasional-kognitif, tetapi juga emosi, fisik dan spiritual. Otak yang optimal adalah otak yang semua potensinya teroptimalkan dengan baik. Untuk dapat mengoptimalkan kerja otak dengan cara yang natural, Barbara menyebutnya sistem pembelajaran alamiah otak, yaitu sistem pembelajaran emosional, sosial, kognitif, fisik dan reflektif. Kelima sistem pembelajaran alamiah otak tersebut merupakan satu kesatuan yang harus ada dalam sistem pembelajaran yang disampaikan oleh guru kepada anak didiknya.

\section{Sistem Pembelajaran Alamiah Otak}

Sistem Pembelajaran alamiah otak, terdiri dari beberapa unsur yang saling menyatu dalam pembelajaran yaitu pembelajaran emosional, sosial, kognitif, fisik dan reflektif (Given,2002:7).

1. Sistem Pembelajaran Emosional Pikiran positif dapat menyebabkan perubahan besar dalam cara otak memproses, menyimpan dan mengambil informasi. Emosi dapat mengubah kemampuan anak didik dalam belajar. Jika secara emosional anak didik senang dan sedang bersemangat maka otak akan melepaskan bahan kimia yang pada gilirannya akan memicu bagian vital otak untuk meminta memori baru ditanam pada berbagai bagian otak.

Emosi adalah perasaan yang ada dalam diri kita, dapat berupa perasaan senang atau tidak senang, perasaan baik ataupun buruk. Dalam Word Book Dictionary (1994) emosi didefinisikan sebagai "berbagai perasaan yang kuat". Perasaan benci, takut, marah, cinta, senang, dan kesedihan. Macam-macam perasaan tersebut adalah gambaran emosi. Goleman (2006) menyatakan bahwa "emosi merujuk pada suatu perasaan atau pikiran-pikiran khasnya, suatu keadaan biologis dan psikologis serta serangkaian kecenderungan untuk bertindak". Misalnya, apabila ada seorang anak yang pemarah dalam suatu kelompok maka dapat mempengaruhi kondisi psikologis lingkungannya saat itu, sehingga suasana permainan menjadi tidak menyenangkan.

Tingkah laku emosi anak yang ditampilkan merupakan sumber penilaian lingkungan sosial terhadap dirinya. Penilaian lingkungan sosial ini akan menjadi dasar individu dalam menilai 
dirinya sendiri. Sebagai contoh, seorang anak sering mengekspresikan ketidaknyamanannya dengan menangis, lingkungan sosialnya akan menilai dia sebagai anak yang "cengeng". Anak akan diperlakukan sesuai dengan penilaiannya tersebut, dan ini akan mempengaruhi kepribadian dan penilaian diri anak.

Selanjutnya, ketegangan emosi yang dimiliki anak dapat menghambat atau mengganggu aktivitas motorik dan mental anak. Misalnya seorang anak akan menolak bermain finger painting karena takut mengotori bajunya dan dimarahi oleh orang tuanya, walaupun sebenarnya aktivitas finger panting ini sangat baik untuk melatih motorik halus. Namun karena hambatan emosional yaitu takut dimarahi ibu/orang tuanya, maka anak akan kehilangan keberanian untuk mencobanya dan hilanglah kesempatan mengembangkan kemampuan dirinya. Sebaliknya, seorang anak yang ramah dan suka menolong merasa senang dengan perilakunya tersebut dan lingkunganpun menyukainya, maka anak akan melakukan perbuatan tersebut berulang-ulang sehingga akhirnya menjadi kebiasaan.

Emosi diperlukan anak dalam kehidupan sehari-hari, bahkan emosi semacam marah dan takut sekalipun. Saat anak mendapatkan kesempatan untuk mengekspresikan emosi, anak mendapatkan pengalaman dan bisa merasakan kesenangan dalam kehidupan sehari-hari.

Emosi juga mempersiapkan tubuh anak untuk melakukan suatu aktivitas. Semakin intens mosi yang terjadi, maka terjadi ketidakseimbangan dalam tubuh sehingga hal ini dapat mendorong tubuh untuk mempersiapkan tindakan tertentu. Jika persiapan tersebut tidak dibutuhkan, maka akan membuat anak gugup ataupun cemas.

Kecerdasan emosional adalah kemampuan seseorang mengatur kehidupan emosinya dengan inteligensi (to manage our emotional life withintelligence), menjaga keselarasan emosi dan pengungkapannya (the appropriateness of emotion and its expression) melalui keterampilan kesadaran diri, pengendalian diri, motivasi diri, empati, dan keterampilan sosial (Bahtiar, 2009).

Kecerdasan emosi anak usia dini adalah kemampuan untuk mengenali, mengolah, dan mengontrol emosi agar anak mampu merespon secara positif setiap kondisi yang merangsang munculnya emosi-emosi. Dengan mengajari anak-anak keterampilan emosi, anak-anak akan lebih mampu mengatasi berbagai masalah yang timbul selama proses perkembangannya menuju manusia dewasa.

Dari beberapa penelitian dalam bidang psikologi anak telah membuktikan bahwa anak-anak yang memiliki kecerdasan emosi yang tinggi adalah anak-anak yang bahagia, percaya diri, populer, dan lebih sukses di sekolah (Wiyani, 2014).

Goleman mengungkapkan bahwa ada tujuh unsur utama pada kecerdasan emosional anak usia dini, yakni:

a. Keyakinan, merupakan perasaan kendali dan penguasaan seorang anak terhadap tubuh, perilaku dan 
dunia, serta perasaan anak bahwa anak lebih cenderung berhasil daripada tidak dalam apa yang dikerjakannya, dan bahwa orangorang dewasa akan bersedia menolongnya.

b. Rasa ingin tahu, merupakan perasaan bahwa menyelidiki segala sesuatu itu bersifat positif dan menimbulkan kesenangan.

c. Niat, merupakan menggambarkan hasrat dan kemampuan untuk berhasil dan untuk bertindak berdasarkan niat itu dengan tekun.

d. Kendali diri, merupakan kemampuan untuk menyesuaikan dan mengendalikan tindakan dengan pola yang sesuai dengan usia, dan merupakan suatu rasa kendali batiniah.

e. Keterkaitan, merupakan kemampuan untuk melibatkan diri dengan orang lain berdasarkan pada perasaan saling memahami.

f. Kecakapan berkomunikasi, merupakan keyakinan dan kemampuan verbal untuk bertukar gagasan, perasaan dan konsep dengan orang lain. Kemampuan ini memiliki keterkaitan dengan rasa percaya pada orang lain, kenyamanan terlibat dengan orang lain, termasuk dengan orang dewasa.

g. Kooperatif, merupakan kemampuan untuk menyeimbangkan kebutuhannya sendiri dengan kebutuhan orang lain dalam kegiatan kelompok.

Pembelajaran berbasis emosi memfasilitasi anak agar memiliki kecerdasan emosi. Selain itu sasaran pembelajaran emosional ini juga adalah mengarahkan diri anak didik untuk memenuhi kebutuhan menjadi diri sendiri. Pembelajaran ini bertujuan untuk memberdayakan diri, mengembangkan hasrat untuk mewujudkan tujuan pribadi anak didik.Untuk itu peran pendidik harus mampu menumbuhkan keinginan itu dari diri anak didik.

Perilaku pendidik dalam pembelajaran emosional adalah sebagai model mentoryaitu sebagai orang yang memberikan stimulasi dan mengarahkan proses pembelajaran yang enjoy dan menyenangkan secara emosi, sehingga anak didik memiliki hasrat untuk belajar. Penampilan dan cara berinteraksi sangat mempengaruhi hasrat anak didik dalam belajar. Untuk itu pendidik dituntut untuk bisa mengemas dan merancang pembelajaran semenarik mungkin.

Sistem pembelajaran emosional ini sangat tepat diterapkan di TK, dimana sebelum memulai pembelajaran guru dapat memulai kegiatan dengan memberikan perasaan senang kepada anak didiknya melalui menyanyi, gerakan dalam nyanyian, permainan-permainan yang akan memunculkan semangat anak TK sebelum memulai aktivitas pembelajaran. Sebagaimana yang 
telah disampaikan sebelumnya, bahwa anak akan lebih mudah diberikan kepadanya dalam suasana yang menyenangkan.

\section{Sistem Pembelajaran Sosial}

Cara kerja alamiah otak yang kedua adalah pembelajaran sosial. Pada proses pembelajaran anak didik selalu berinteraksi dengan kelompok sosialnya, baik anak didik dengan anak didik, anak didik dengan pendidik dan anak didik dengan sumber belajar lainnya. Anak didik tidak akan mampu memahami pembelajaran tanpaada interaksi sosial dengan orang lain.

Pembelajaran sosial memiliki sasaran untuk meyakinkan diri anak didik tentang kebutuhan untuk menjadi bagian dari kelompok. Pembelajaran sosial ini bisa melalui kolaborasi, interaksi dengan pendidik, atau dengan anak didik lain untuk mengembangkan visi yang jelas mencapai tujuan.

Anak didik akan mampu menggambarkan sendiri tentang apa yang telah dipelajari berdasarkan pengalaman yang dilalui berdasarkan dari kolaborasi. Pendidik dapat menciptakan sistem pembelajaran sosial dengan menciptakan hubungan dan relasi yang erat dengan anak didik. Akibatnya anak didik merasa dekat dan tercipta hubungan sosial yang positif dengan pendidiknya. Pembelajaran sosial juga dapat diciptakan dengan kerjasama kelompok, yang kooperatif dan menyen7angkan. menyerap informasi yang

Adanya sistem pembelajaran sosial ini, akan memfasilitasi anak TK untuk lebih mengembangkan kemampuan mereka dalam berelasi sosial. Sebagaimana yang terdapat dalam Peraturan Menteri no. 58 tahun 2009, dimana anak TK perlu mendapat stimulasi dalam aspek perkembangan sosial emosionalnya. Dengan adanya sistem pembelajaran ini, anak akan lebih terlatih untuk dapat berinteraksi sesuai dengan tuntutan yang ada di lingkungannya.

\section{Sistem Pembelajaran Kognitif}

Dari perspektif brain basedteaching, selain bertanya, cara yang paling efektif untuk mengajarkan keterampilan berfikir adalah menggabungkan masalah dunia nyata dalam kondisi-kondisi otentik. Pembelajaran kognitif adalah pembelajaran yang bertujuan untuk mengetahui.

Peran pendidik dalam pembelajaran ini adalah sebagai fasilitator dengan pengenali pengetahuan dan kecakapan yang dibutuhkan anak didik untuk mencapai tujuan. Pembelajaran adalah sebuah proses yang interaktif yang terjadi pada berbagai tingkatan. Pembelajaran sebaiknya dimulai dengan memasukkan, menyaring, menggabung, memproses, mengevaluasi dan menyimpan untuk digunakan berikutnya.

Keinginan untuk lebih memahami dan mengetahui dari anak didukung oleh berbagai cara yang 
dirancang dan dilaksanakan oleh guru. Keingintahuan anak difasilitasi dengan banyak memberikan kesempatan kepada anak berekplorasi baik melalui visual ataupun audio serta kinestetik yang dapat dilakukan anak di dalam kelas maupun di luar kelas.

\section{Pembelajaran kognitif berarti} pembelajaran yang mampu menanamkan konsep-konsep atau materi pembelajaran dalam sistem alamiah otak melalui berbagai cara yang digunakan.

Sistem pembelajaran kognitif di TK biasanya lebih banyak digunakan para guru di TK daripada sistem pembelajaran lainnya. Hal ini dikarenakan, mereka menganggap bahwa pembelajaran haruslah identik dengan aspek kognitif.

Pembelajaran kognitif yang diberikan oleh para guru TK, hanya terbatas pada pembelajaran berhitung yang konvensional dengan metode dan media yang tidak bervariasi. Mereka tidak memfasilitasi anak didiknya untuk berekplorasi melalui visual ataupun audio serta kinestetik yang dapat dilakukan anak di dalam kelas maupun di luar kelas. Selain itu juga, tidak adanya penyampaian materi yang sistematis, dimana menurut sistem pembelajaran kognitif, pembelajaran sebaiknya dimulai dengan memasukkan, menyaring, menggabung, memproses, mengevaluasi dan menyimpan untuk digunakan berikutnya.
Sistem pembelajaran kognitif adalah sistem pemrosesan informasi pada otak. Sistem ini menyerap input dari dunia luar dan semua sistem lain, menginterpretasikan input tersebut, serta memandu pemecahan masalah dan pengambilan keputusan.

Tugas paling berat sistem kognitif di antaranya menilai sensasi emosional dan situasi sosial, kemudian mengambil tindakan berdasarkan penilaian tersebut untuk tetap memegang kendali atas emosi primer sambil mempertimbangkan kebutuhan untuk menjadi bagian dari masyarakat.

Sistem pembelajaran kognitif otak paling banyak menerima perhatian karena sistem ini berhubungan dengan membaca, menulis, berhitung dan semua aspek lain dalam pengembangan kecakapan akademis. Perhatian pada sistem kognitif menempatkan guru pada peran fasilitator pembelajaran dan anak pada peran pemecah masalah dan pengambilan keputusan nyata. Sistem pembelajaran ini memfasilitasi anak untuk menstimulasi berbagai aspek kecerdasannya, yaitu Multiple Intelligence/ kecerdasan jamaknya.

Mendengarkan, berbicara, membaca, menulis, dan perkembangkan kecakapan akademis lainnya bergantung pada sistem kognitif. Sistem kognitif mengandalkan input sensoris dan berfungsinya perhatian, pemrosesan informasi, dan beberapa subsistem memori secara memadai untuk mengonstruksi pengetahuan dan 
kecakapan. Yang juga penting, sistem kognitif berfungsi paling baik jika sistem sistem lain (emosional, sosial, fisik, atau reflektif) tidak bersaing menarik perhatian. Jika sistem-sistem cenderung bersaing dan bukan bekerja sama, pembelajaran secara drastis menurun. Masih ada aspek penting lain agar sistem kognitif berfungsi efektif dikelas, yaitu guru harus menunjukan minat dan memahami dengan baik kandungan materi yang mereka ajarkan.

Sistem pembelajaran kognitif berkembang dengan kuat jika ada tantangan mental dan masalah untuk dipecahkan, dengan kata lain adalah manusia dirancang untuk belajar. Pembelajaran sama alamiahnya dengan bernafas, dan itu tidak bisa dihentikan kecuali terjadi kerusakan otak. Bahkan jika itu tejadi, kebutuhan untuk mengetahui biasanya tetap ada.

Tujuan sistem pembelajaran kognitif adalah mengembangkan pengetahuan dan kecakapan baru. Sistem ini juga sengaja merencanakan dan bersiap-siap untuk mewujudkan hasrat dari sistem pembelajaran emosional dan visi yang dihasilkan dari interaksi budaya. Tidak diragukan, kebanyakan anak-anak memasuki sekolah dengan hasrat yang besar untuk memenuhi kebutuhan kuat untuk mengetahui, tetapi jika mereka gagal menyamai teman-teman sekelas, kebutuhan itu tidak terpenuhi, dan belajar membaca, menulis, dan berhitung akan menjadi tugas-tugas sulit.
Disinilah peran guru untuk bisa merangsang dan menfasilitasi pembelajaran pada semua anak dengan menangani kebutuhan untuk mengetahui dengan cara beragam. Guru harus memfasilitasi pembelajaran dengan memberikan pelajaran yang mengoptimalkan setiap sistem pembelajaran alamiah. Dengan menyediakan berbagai cara belajar melalui sistem-sistem yang berbeda, anak bebas memperoleh informasi baru dengan cara yang paling nyaman bagi mereka.

\section{Sistem Pembelajaran Fisik}

Dalam sistem pembelajaran fisik, aktivitas anak didik dilakukan melalui berbagai kegiatan nyata secara langsung. Aktivitas ini dapat dilakukan tidak hanya di ruang kelas, namun juga dapat dilakukan di halaman sekolah dengan berbagai alat bantu dan sumber belajar. Dengan berbagai aktivitas nyata ini anak didik akan dihadapkan langsung dengan fenomena yang akan dipelajari, dengan demikian berbagai aktivitas ini memungkinkan terjadi proses belajar aktif.

Pembelajaran fisik merupakan prinsip atau asas yang sangat penting dalam interaksi pembelajaran. Hal ini disebabkan karena pembelajaran adalah berbuat untuk mengubah tingkah laku melalui kegiatan. Aktivitas anak didik adalah seluruh kegiatan yang dilakukan anak didik selama proses pembelajaran.

Pembelajaran fisik memiliki sasaran untuk memenuhi kebutuhan untuk melakukan. Peran pendidik 
pada pembelajaran ini adalah sebagai pelatih karena pendidik harus psikomotor anak didik. Dalam pembelajaran ini pendidik harus menciptakan pembelajaran aktif dengan melakukan tindakan/gerakan motorik untuk mencapai tujuan pembelajaran.

Perkembangan motorik
merupakan perkembangan
pengendalian gerakan jasmaniah
melalui kegiatan pusat syaraf, urat
syaraf dan otot terkoordinasi
(Hurlock: 1998). Keterampilan
motorik anak terdiri atas
keterampilan motorik kasar dan
keterampilan motorik halus.
Keterampilan motorik anak usia 4-5
tahun lebih banyak berkembang pada
motorik kasar, setelah usia 5 tahun
baru.terjadi perkembangan motorik
halus.

Sujiono (2009: 1.14) berpendapat, motorik halus adalah gerakan yang hanya melibatkan bagian-bagian tubuh tertentu saja dan dilakukan oleh otot-otot kecil, seperti keterampilan menggunakan jari jemari tangan dan gerakan pergelangan tangan yang tepat. Sehingga gerakan ini tidak memerlukan tenaga melainkan membutuhkan koordinasi mata dan tangan yang cermat. Dalam melakukan gerakan motorik halus, anak juga memerlukan dukungan keterampilan fisik lain serta kematangan mental.

Menurut Papalia (2008) 7 Prinsip Pengembangan Motorik Halus Anak Usia Dini PAUD dalam mengembangkan

pembelajaran mengembangkan otak anak

1. Memberikan kebebasan ekspresi pada anak. Ekspresi adalah proses pengungkapan perasaan dan jiwa secara jujur dan langsung dari dalam diri anak.

2. Melakukan pengaturan waktu, tempat, media (alat dan bahan) agar dapat merangsang anak untuk kreatif. Kreativitas merupakan kemampuan mencipta sesuatu yang baru yang bersifat orisinil/asli dari dirinya sendiri. Kreativitas erat kaitannya dengan fantasi (daya khayal), karena itu anak perlu diaktifkan dengan cara membangkitkan tanggapan melalui pengamatan dan pengalamannnya sendiri. Untuk mendukung anak dalam merangsang kreativitasnya perlu dialokasikan waktu, tempat, dan media yang cukup.

3. Memberikan bimbingan kepada anak untuk menemukan teknik/cara yang baik dalam melakukan kegiatan dengan berbagai media. Ketika melakukan kegiatan motorik halus, anak menggunakan berbagai macam media/alat dan bahan, oleh karena itu perlu kiranya anak mendapatkan contoh dan menguasai berbagai cara menggunakan alat-alat tersebut, sehingga anak merasa yakin akan kemampuannya dan tidak mengalami kegagalan. Latihan menggunakan alat ini dapat dilakukan dengan berbagai 
gerakan sederhana misalnya bermain jari (finger plays).

4. Menumbuhkan keberanian anak dan hindarkan petunjuk yang dapat merusak keberanian dan perkembangan anak. Hindari komentar negatif ketika melihat hasil karya motorik halus anak, begitu pula kata-kata yang membatasi berupa larangan atau petunjuk yang terlalu banyak serta labeling kepada anak. Hal-hal tersebut dapat menyebabkan anak berkecil hati, kurang percaya diri dan frustasi dengan kemampuannya. Berikan motivasi dengan kata-kata positif, pujian, dorongan dan reward lainnya sehingga anak termotivasi untuk terus mengem-bangkan kemampuannnya.

5. Membimbing anak sesuai dengan kemampuan dan taraf perkembangan. Dalam perkembangan anak terdapat karakteristik perkembangan yang berbeda-beda untuk tiap usia. Karena itu perlu kiranya memperhatikan apa dan bagaimana bimbingan dan stimulai yang dapat diberikan kepada anak sesuai dengan usia perkembangannya.

6. Memberikan rasa gembira dan ciptakan suasana yang menyenangkan pada anak. Anak akan melakukan kegiatan dengan seoptimal mungkin jika ia berada dalam kondisi psikologis yang baik, yaitu dalam suasana yang menyenangkan hatinya tanpa ada tekanan. Karena itu perlu menciptakan suasana yang memberikan kenyamanan psiklogis kepada anak dalam berkarya motorik halus.

7. Melakukan pengawasan menyeluruh terhadap pelaksanaan kegiatan. Dalam mengembangkan kegiatan motorik halus orang dewasa perlu memberikan perhatian yang memadai pada anak, hal ini untuk mendorong anak dan sekaligus menghidari terjadinya hal-hal yang tidak diinginkan seperti pertengkaran memperebutkan alat berkarya, atau kegagalan membuat karya atau bahkan kecelakaan ketika anak tidak berhati-hati menggunakan alat, seperti gunting.

8. Perkembangan motorik adalah proses tumbuh kembang kemampuan gerak seorang anak. Pada dasarnya, perkembangan ini berkembang sejalan dengan kematangan saraf dan otot anak. Sehingga, setiap gerakan sesederhana apapun merupakan hasil pola interaksi yang kompleks dari berbagai bagian dan system dalam tubuh yang dikontrol oleh otak. Kemampuan motorik terbagi dua yaitu motorik kasar dan motorik halus. Menurut Syamsyudin (dalam Widarmi:2008)., Motorik kasar adalah aktivitas dengan menggunakan otot-otot besar yang meliputi gerak dasar lokomotor, nonlokomotor.

Gerak Motorik Kasar adalah kemampuan yang membutuhkan koordinasi sebagian besar bagian tubuh anak. Oleh karena itu, biasanya 
memerlukan tenaga karena dilakukan oleh otot-otot yang lebih besar. Motorik kasar anak akan berkembang sesuai dengan usianya (age appropriateness). Orang dewasa tidak perlu melakukan bantuan terhadap kekuatan otot besar anak. Jika anak telah matang, maka dengan sendirinya anak akan melakukan gerakan yang sudah waktunya untuk dilakukan.

Pentingnya meningkatkan perkembangan motorik, diantaranya :

1. Peran kemampuan motorik untuk perkembangan fisiologis anak

2. Peran kemampuan motorik untuk perkembangan sosial dan emosional anak

3. Peran kemampuan motorik untuk kognitif anak

Secara langsung pertumbuhan anak akan menentukan keterampilannya dalam bergerak, sedangkan secara tidak langsung, pertumbuhan dan kemampuan fisik atau motorik anak akan mempengaruhi cara anak memandang dirinya sendiri dan orang lain.

Seorang anak yang mempunyai kemampuan motorik yang baik akan mempunyai rasa percaya diri yang besar. Lingkungan teman-temannya pun akan menerima anak yang memiliki kemampuan motorik dan gerak lebih baik, sedangkan anak yang tidak memiliki atau kurang kemampuan motorik atau gerak tertentu akan kurang diterima teman-temannya. Penelitian otak juga menjelaskan bahwa anak-anak yang beraktivitas akan memperkuat jalinan selsel syarafnya (Widarmi, 2008).
Dengan adanya aktivitas fisik, maka kinerja fisik akan memicu otak untuk menguatkan memori dan meningkatkan koneksi antara saraf-saraf. Gerakan membantu anak didik membuat keterhubungan di dalam otak. Kegiatan fisik akan mampu mengatasi kebosanan dan kevakuman anak dalam proses pembelajaran. Anak dalam rentang ini menginginkan gerak tubuh yang luwes untuk bisa belajar.

Gerakan fisik dalam pembelajaran di TK dapat dilakukan dengan berbagai cara diantaranya melalui percobaan, menari, permainan dan berbagai cara yang relevan dengan materi dan tujuan yang diinginkan.

\section{Sistem Pembelajaran Reflektif}

Sistem cara kerja alamiah otak yang kelima adalah pembelajaran reflektif. Anak TK memiliki rasa ingin tahu untuk menggali berbagai pengetahuan baru, dan akhirnya dapat mengaplikasikannya dalam kehidupan mereka. Ini tentu saja sangat ditunjang dengan pekembangan dan meningkatnya rasa ingin tahu anak didik.

Kegiatan refleksi bisa dilakukan dengan meminta anak didik merinci kembali materi yang sudah dipelajari dengan bahasa mereka sendiri. Selanjutnya bisa dilakukan dengan meminta anak didik untuk menjelaskan manfaat mempelajari materi tersebut.

Refleksi juga bisa dilanjutkan dengan meminta anak didik untuk menjelaskan hal-hal yang menarik tentang materi yang telah mereka pelajari.

Otak menyerap informasi dari lingkungan sekeliling, baik pada level 
sadar maupun tidak sadar. Untuk itu kelas harus dirancang sedemikian rupa sehingga dapat menstimulisasi otak dalam beraktivitas. Karena dengan penataan lingkungan seperti warna, gambar, penerangan alamiah adalah yang terbaik untuk pembelajaran.

Sistem pembelajaran ini memungkin anak TK untuk mencari dan menemukan makna dari setiap informasi atau materi pembelajaran yang diberikan. Anak didik dengan kegiatannya mampu terlibat secara fisik dan mental. Dalam sistem ini, guru menyediakan variasi stimulasi bagi anak didik melalui

\section{HASIL}

Berdasarkan hasil analisis angket mengenai pengetahuan guru mengenai berbagai metode pembelajaran. Selanjutnya perlu membuat anak didik aktif dengan melakukan presentasi yang sesuai dengan kemampuan dan minat mereka.

\section{METODE}

Metode yang digunakan dalam penelitian ini adalah metode deskriptif. Alat yang digunakan dalam mengambil data adalah angket dan kuesioner. Metode analisis yang digunakan adalah Analisis Deskriptif Persentase.

pembelajaran berbasis kinerja otak, maka dapat dideskripsikan sebagai berikut:

Tabel Pengetahuan Guru

Mengenai System Pembelajaran Alamiah Otak

\begin{tabular}{|c|c|c|}
\hline Dimensi & Indikator & $\%$ \\
\hline \multirow[t]{3}{*}{$\begin{array}{l}\text { Sistem pembelajaran } \\
\text { emosional }\end{array}$} & $\begin{array}{l}\text { 1. Menunjukkan antusiasme yang } \\
\text { tulus kepada anak }\end{array}$ & 100 \\
\hline & $\begin{array}{l}\text { 2. Membantu anak menemukan } \\
\text { hasrat belajar }\end{array}$ & 100 \\
\hline & $\begin{array}{l}\text { 3. Membimbing anak mencapai } \\
\text { apa yang bisa mereka capai }\end{array}$ & 96 \\
\hline \multirow[t]{3}{*}{$\begin{array}{l}\text { Sistem pembelajaran } \\
\text { social }\end{array}$} & $\begin{array}{l}\text { 1. Bekerja sama dalam } \\
\text { pengambilan keputusan }\end{array}$ & 96 \\
\hline & $\begin{array}{l}\text { 2. Bekerjasama dalam pemecahan } \\
\text { masalah yang nyata }\end{array}$ & 100 \\
\hline & $\begin{array}{l}\text { 3. Mengajari anak mengatasi } \\
\text { masalah bersama dengan } \\
\text { temannya }\end{array}$ & 100 \\
\hline Sistem pembelajaran & 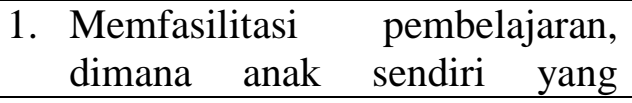 & 96 \\
\hline
\end{tabular}




\begin{tabular}{|c|c|c|c|}
\hline \multirow[t]{3}{*}{ kognitif } & \multicolumn{3}{|c|}{ mengambil keputusan } \\
\hline & & $\begin{array}{l}\text { Memfasilitasi pembelajaran, } \\
\text { dimana anak yang memecahkan } \\
\text { sendiri masalahnya }\end{array}$ & 92 \\
\hline & & $\begin{array}{l}\text { Mengkaitkan pembelajaran } \\
\text { dengan dunia nyata }\end{array}$ & 96 \\
\hline \multirow[t]{4}{*}{$\begin{array}{l}\text { System } \\
\text { pembelajaran fisik }\end{array}$} & & $\begin{array}{l}\text { Mengubah input dari indra dan } \\
\text { sistem internal menjadi tindakan }\end{array}$ & 96 \\
\hline & & $\begin{array}{l}\text { Guru berperan sebagai pelatih } \\
\text { yang bisa melatih dan } \\
\text { mengilhami siswa dalam } \\
\text { mengelola pembelajaran fisik } \\
\text { untuk melakukan aktivitas } \\
\text { tangan dan gerakan tubuh }\end{array}$ & 92 \\
\hline & & $\begin{array}{lr}\text { Mengarahkan } & \text { energi fisik } \\
\text { mereka untuk mendukung } \\
\text { pertumbuhan pribadi dan } \\
\text { akademis r sekaligus } \\
\text { pertumbuhan } \\
\text { yang lain }\end{array}$ & 84 \\
\hline & & $\begin{array}{l}\text { Pertimbangan pribadi terhadap } \\
\text { pembelajarannya sendiri dengan } \\
\text { menimbang prestasi dan } \\
\text { kegagalannya serta menanyakan } \\
\text { mana yang berhasil, mana yang } \\
\text { tidak, dan mana yang perlu } \\
\text { ditingkatkan. }\end{array}$ & 92 \\
\hline \multirow[t]{3}{*}{$\begin{array}{l}\text { Sistem pembelajaran } \\
\text { reflektif }\end{array}$} & 1 & $\begin{array}{l}\text { Menuntut siswa } \\
\text { memahami diri sendiri }\end{array}$ & 96 \\
\hline & & $\begin{array}{l}\text { Guru bertindak sebagai pencari } \\
\text { bakat yang mengenali kelebihan } \\
\text { siswa kemudian membimbing } \\
\text { dan memupuk kelebihan siswa } \\
\text { itu menjadi bakat nyata }\end{array}$ & 90 \\
\hline & 3 & $\begin{array}{l}\text { Guru mengajari siswa } \\
\text { bagaimana mereka belajar dan } \\
\text { menggunakan gaya belajar yang }\end{array}$ & 88 \\
\hline
\end{tabular}




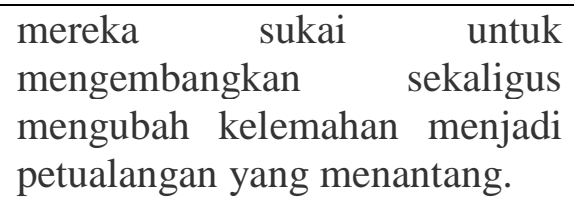

\section{Pembahasan}

Pembahasan hasil penelitian adalah sebagai berikut:

1. Pengetahuan guru mengenai sistem pembelajaran emosional di TK Mujahidin 1 Pontianak

Pembelajaran ini bertujuan untuk memberdayakan diri, mengembangkan hasrat untuk mewujudkan tujuan pribadi anak didik.Untuk itu peran pendidik harus mampu menumbuhkan keinginan itu dari diri anak didik. Perilaku pendidik dalam pembelajaran emosional adalah sebagai model mentoryaitu sebagai orang yang memberikan stimulasi dan mengarahkan proses pembelajaran yang enjoy dan menyenangkan secara emosi, sehingga anak didik memiliki hasrat untuk belajar. Penampilan dan cara berinteraksi sangat mempengaruhi hasrat anak didik dalam belajar. Untuk itu pendidik dituntut untuk bisa mengemas dan merancang pembelajaran semenarik mungkin. Sistem pembelajaran emosional ini sangat tepat diterapkan di TK, dimana sebelum memulai pembelajaran guru dapat memulai kegiatan dengan memberikan perasaan senang kepada anak didiknya melalui menyanyi, gerakan dalam nyanyian, permainan-permainan yang akan memunculkan semangat anak TK sebelum memulai aktivitas pembelajaran. Sebagaimana yang telah disampaikan sebelumnya, bahwa anak akan lebih mudah menyerap informasi yang diberikan kepadanya dalam suasana yang menyenangkan.

Sejalan dengan teori diatas, data hasil penelitian menunjukkan semua guru memiliki antusiasme yang tulus kepada anak didiknya dan membantu anak menemukan hasrat belajarnya $(100 \%)$. Dari 24 guru yang dijadikan subyek penelitian, 23 guru membimbing anak didinya mencapai apa yang bisa mereka capai, yaitu sebanyak $96 \%$.

2. Pengetahuan guru mengenai sistem pembelajaran sosial TK Mujahidin 1 Pontianak

Pada proses pembelajaran sosial, anak didik selalu berinteraksi dengan kelompok sosialnya, baik anak didik dengan anak didik, anak didik dengan pendidik dan anak didik dengan sumber belajar lainnya. Anak didik tidak akan mampu memahami pembelajaran tanpaada interaksi sosial dengan orang lain.

Pembelajaran sosial memiliki sasaran untuk meyakinkan diri anak didik tentang kebutuhan untuk menjadi bagian dari kelompok. Pembelajaran sosial ini bisa melalui 
kolaborasi, interaksi dengan pendidik, atau dengan anak didik lain untuk mengembangkan visi yang jelas mencapai tujuan.

Anak didik akan mampu menggambarkan sendiri tentang apa yang telah dipelajari berdasarkan pengalaman yang dilalui berdasarkan dari kolaborasi. Pendidik dapat menciptakan sistem pembelajaran sosial dengan menciptakan hubungan dan relasi yang erat dengan anak didik. Akibatnya anak didik merasa dekat dan tercipta hubungan sosial yang positif dengan pendidiknya. Pembelajaran sosial juga dapat diciptakan dengan kerjasama kelompok, yang kooperatif dan menyenangkan.

Data hasil penelitian menunjukkan bahwa sebanyak 23 orang guru dari 24 guru yang menjadi subyek penelitian dapat bekerja sama dalam pengambilan keputusan bekerjasama dalam pemecahan masalah yang nyata, yaitu sebesar 96\%. Semua guru dapat mengajari anak mengatasi masalah bersama dengan temannya memfasilitasi pembelajaran, dimana anak sendiri yang mengambil keputusan (100\%).

3. Pengetahuan guru mengenai sistem pembelajaran kognitif di TK Mujahidin 1 Pontianak

Cara yang paling efektif untuk mengajarkan keterampilan berfikir adalah menggabungkan masalah dunia nyata dalam kondisikondisi otentik. Pembelajaran kognitif adalah pembelajaran yang bertujuan untuk mengetahui.
Peran pendidik dalam pembelajaran ini adalah sebagai fasilitator dengan pengenali pengetahuan dan kecakapan yang dibutuhkan anak didik untuk mencapai tujuan. Pembelajaran adalah sebuah proses yang interaktif yang terjadi pada berbagai tingkatan. Pembelajaran sebaiknya dimulai dengan memasukkan, menyaring, menggabung, memproses, mengevaluasi dan menyimpan untuk digunakan berikutnya.

Keinginan untuk lebih memahami dan mengetahui dari anak didukung oleh berbagai cara yang dirancang dan dilaksanakan oleh guru. Keingintahuan anak difasilitasi dengan banyak memberikan kesempatan kepada anak berekplorasi baik melalui visual ataupun audio serta kinestetik yang dapat dilakukan anak di dalam kelas maupun di luar kelas.

Pembelajaran kognitif berarti pembelajaran yang mampu menanamkan konsep-konsep atau materi pembelajaran dalam sistem alamiah otak melalui berbagai cara yang digunakan.

Sistem pembelajaran kognitif di TK biasanya lebih banyak digunakan para guru di TK daripada sistem pembelajaran lainnya. Hal ini dikarenakan, mereka menganggap bahwa pembelajaran haruslah identik dengan aspek kognitif.

Pembelajaran kognitif yang diberikan oleh para guru TK, hanya terbatas pada pembelajaran berhitung yang konvensional dengan metode dan media yang tidak bervariasi. Mereka tidak 
memfasilitasi anak didiknya untuk berekplorasi melalui visual ataupun audio serta kinestetik yang dapat dilakukan anak di dalam kelas maupun di luar kelas. Selain itu juga, tidak adanya penyampaian materi yang sistematis, dimana menurut sistem pembelajaran kognitif, pembelajaran sebaiknya dimulai dengan memasukkan, menyaring, menggabung, memproses, mengevaluasi dan menyimpan untuk digunakan berikutnya. Disinilah peran guru untuk bisa merangsang dan menfasilitasi pembelajaran pada semua anak dengan menangani kebutuhan untuk mengetahui dengan cara beragam.

Guru harus memfasilitasi pembelajaran dengan memberikan pelajaran yang mengoptimalkan setiap sistem pembelajaran alamiah. Dengan menyediakan berbagai cara belajar melalui sistem-sistem yang berbeda, anak bebas memperoleh informasi baru dengan cara yang paling nyaman bagi mereka.

Data hasil penelitian menunjukkan, bahwa sebanyak 23 orang guru dari 24 orang guru di TK Mujahidin 1 Pontianak dapat memfasilitasi pembelajaran, dimana anak sendiri yang mengambil keputusan dan dapat engkaitkan pembelajaran dengan dunia nyata (96\%). 22 orang guru dapat memfasilitasi pembelajaran, dimana anak yang memecahkan sendiri masalahnya $(92 \%)$.

4. Pengetahuan guru mengenai sistem pembelajaran fisik di TK Mujahidin 1 Pontianak
Dalam sistem pembelajaran fisik, aktivitas anak didik dilakukan melalui berbagai kegiatan nyata secara langsung. Aktivitas ini dapat dilakukan tidak hanya di ruang kelas, namun juga dapat dilakukan di halaman sekolah dengan berbagai alat bantu dan sumber belajar. Dengan berbagai aktivitas nyata ini anak didik akan dihadapkan langsung dengan fenomena yang akan dipelajari, dengan demikian berbagai aktivitas ini memungkinkan terjadi proses belajar aktif.

Pembelajaran fisik merupakan prinsip atau asas yang sangat penting dalam interaksi pembelajaran. Hal ini disebabkan karena pembelajaran adalah berbuat untuk mengubah tingkah laku melalui kegiatan. Aktivitas anak didik adalah seluruh kegiatan yang dilakukan anak didik selama proses pembelajaran.

Pembelajaran fisik memiliki sasaran untuk memenuhi kebutuhan untuk melakukan. Peran pendidik pada pembelajaran ini adalah sebagai pelatih karena pendidik harus mengembangkan psikomotor anak didik. Dalam pembelajaran ini pendidik harus menciptakan pembelajaran aktif dengan melakukan tindakan/gerakan motorik untuk mencapai tujuan pembelajaran.

Data hasil penelitian menunjukkan guru yang dapat mengubah input dari indra dan sistem internal menjadi tindakan sebanyak 96\%, guru yang dapat berperan sebagai pelatih yang bisa melatih dan mengilhami siswa dalam mengelola pembelajaran fisik untuk 
melakukan aktivitas tangan dan gerakan tubuh sebanyak 92\%, guru yang dapat mengarahkan energi fisik mereka untuk mendukung pertumbuhan pribadi dan akademis sekaligus pertumbuhan sistem-sistem otak yang lain sebanyak $84 \%$ dan guru yang memiliki pertimbangan pribadi terhadap pembelajarannya sendiri dengan menimbang prestasi dan kegagalannya serta menanyakan mana yang berhasil, mana yang tidak, dan mana yang perlu ditingkatkan sebanyak $92 \%$.

5. Pengetahuan guru mengenai sistem pembelajaran reflektif di TK Mujahidin 1 Pontianak

$$
\text { Kegiatan refleksi bisa }
$$
dilakukan dengan meminta anak didik merinci kembali materi yang sudah dipelajari dengan bahasa mereka sendiri. Selanjutnya bisa dilakukan dengan meminta anak didik untuk menjelaskan manfaat mempelajari materi tersebut.

Refleksi juga bisa dilanjutkan dengan meminta anak didik untuk menjelaskan hal-hal yang menarik tentang materi yang telah mereka pelajari. Otak menyerap informasi dari lingkungan sekeliling, baik pada level sadar maupun tidak sadar. Untuk itu kelas harus dirancang sedemikian rupa sehingga dapat

\section{KESIMPULAN DAN SARAN Kesimpulan}

Berdasarkan hasil analisis data dan pembahasan, diperoleh gambaran bahwa pengetahuan guru mengenai pembelajaran berbasis kinerja otak adalah menstimulisasi otak dalam beraktivitas. Karena dengan penataan lingkungan seperti warna, gambar, penerangan alamiah adalah yang terbaik untuk pembelajaran.

Sistem pembelajaran ini memungkin anak TK untuk mencari dan menemukan makna dari setiap informasi atau materi pembelajaran yang diberikan. Anak didik dengan kegiatannya mampu terlibat secara fisik dan mental. Dalam sistem ini, guru menyediakan variasi stimulasi bagi anak didik melalui berbagai metode pembelajaran. Selanjutnya perlu membuat anak didik aktif dengan melakukan presentasi yang sesuai dengan kemampuan dan minat mereka.

Data hasil penelitian menunjukkan sebanyak $96 \%$ guru menuntut siswa untuk memahami diri sendiri, sebanyak 90\% guru bertindak sebagai pencari bakat yang mengenali kelebihan siswa kemudian membimbing dan memupuk kelebihan siswa itu menjadi bakat nyata dan sebanyak $88 \%$ guru harus mengajari siswa bagaimana mereka belajar dan bagaimana menggunakan gaya belajar yang mereka sukai untuk mengembangkan sekaligus mengubah kelemahan menjadi petualangan pertumbuhan yang menantang.

baik. Secara spesifik akan dijelaskan di bawah ini:

1. Pengetahuan guru mengenai system pembelajaran emosional sudah baik, guru mengetahui bahwa dalam pembelajaran mereka harus dapat menunjukkan antusiasme yang tulus 
kepada anak membantu anak menemukan hasrat belajar, Membimbing anak mencapai apa yang bisa mereka capai

2. Pengetahuan guru mengenai system pembelajaran social sudah baik, para guru memiliki pengetahuan tentang perlunya bekerja sama dalam pengambilan keputusan bekerjasama dalam pemecahan masalah yang nyata mengajari anak mengatasi masalah bersama dengan temannya.

3. Pengetahuan guru mengenai system pembelajaran kognitif sudah baik, dimana guru memiliki pengetahuan tentang perlunya memfasilitasi pembelajaran, dimana anak sendiri yang mengambil keputusan, memfasilitasi pembelajaran, dimana anak yang memecahkan sendiri masalahnya, Mengkaitkan pembelajaran dengan dunia nyata.

4. Pengetahuan guru mengenai system pembelajaran fisik sudah baik. Para guru di TK Mujahidin mengetahui perlunya mengubah input dari indra dan sistem internal menjadi tindakan, guru berperan sebagai pelatih yang bisa melatih dan mengilhami siswa dalam mengelola pembelajaran fisik untuk melakukan aktivitas tangan dan gerakan tubuh, mengarahkan energi fisik mereka untuk mendukung pertumbuhan pribadi dan akademis sekaligus pertumbuhan sistem-sistem otak yang lain pertimbangan pribadi terhadap pembelajarannya sendiri dengan menimbang prestasi dan kegagalannya serta menanyakan mana yang berhasil, mana yang tidak, dan mana yang perlu ditingkatkan.
5. Pengetahuan guru mengenai system pembelajaran reflektif sudah baik. Guru mengetahui perlunya menuntut siswa untuk memahami diri sendiri, bertindak sebagai pencari bakat yang mengenali kelebihan siswa kemudian membimbing dan memupuk kelebihan siswa itu menjadi bakat nyata, mengajari siswa bagaimana mereka belajar dan bagaimana menggunakan gaya belajar yang mereka sukai untuk mengembangkan sekaligus mengubah kelemahan menjadi petualangan pertumbuhan yang menantang.

\section{Saran}

Berdasarkan hasil kesimpulan yang telah dikemukakan di atas, maka disarankan kepada para guru di TK Mujahidin untuk dapat membagi ilmu yang mereka ketahui tentang pembelajaran berbasis kinerja otak kepada para guru TK lain di kota Pontianak, agar para guru TK lain memiliki pengetahuan tentang pembelajaran berbasis kinerja otak yang sesuai dalam pembelajaran di TK.

\section{DAFTAR RUJUKAN}

Adi W. Gunawan. 2007. Genius Learning Strategy. Petunjuk Praktis untuk Menerapkan Accelerated Learning. Jakarta: PT. Gramedia Pustaka Utama.

Bahtiar. 2009. Hubungan Antara Kecerdasan Emosional dengan Prestasi Belajar Anak kelas II SMA Negeri 2 Mataram. Jurnal Pemikiran Alternatif Pendidikan, Vol 14 (12), 254-268

Given, Barbara K. 2007. Brain Based Teaching. Merancang Kegiatan Belajar-Mengajar yang 
Melibatkan Otak Emosional, Sosial, Kognitif, Kinestetis dan Reflektif. Penerjemah: LalaHerawati Dharma. Bandung: PT. MizanPustaka.

Goleman, Daniel. 2006. Emotional Intelegence, Kecerdasan Emosional "Mengapa EI Lebih Penting dari IQ". Terjemahan oleh $\mathrm{T}$ Hermaya. Jakarta: Gramedia Pustaka Utama.

Hadari Nawawi. 1983. Metode Penelitian Bidang Sosial. Yogyakarta: Gajah Mada University Press.

Hurlock, E.B 1988. Psikologi Perkembangan Suatu Pendekatan Sepanjang Rentan Kehidupan (Edisi kelima). Jakarta: Erlangga.

Hurlock, Elizabeth B. 1998. Psikologi Perkembangan, terj. Istiwidiyanti dan Soedjarwo. Jakarta: Erlangga

Munif Chatib. 2011. Gurunya Manusia. Bandung: Kaifa
Notoadmojo, Soekidjo 2005. Promosi Kesehatan, Teori dan Aplikasi. Jakarta: PT. Rineka Cipta

Notoadmojo, Soekidjo. 2007. Promosi Kesehatan dan Ilmu Perilaku. Jakarta: PT. Rineka Cipta

Papalia, Diane E, Etc. 2008. Human Development (Psikologi Perkembangan, terjemahan A. K. Anwar). Jakarta: Kencana Prenada Media Grup

Peraturan Menteri no. 58 tahun 2009

Sudjana. 2001. Metode Statistika. Edisi Revisi. Cetakan Keenam. Bandung: Tarsito

Widarmi, D., Sriratna, G., dan Yulianti. 2008. Kurikulum Pendidikan Anak Usia Dini (Edisi kesatu). Jakarta: Universitas Terbuka

Wiyani, Novan Ardy. 2014. Psikologi Perkembangan Anak Usia Dini. Yogyakarta : Gava Media.

Yuliani Nurani Sujiono. 2009. Konsep

Dasar PAUD. Jakarta. Indeks 